ISSN 2413-0877 Volume 1 (2015)

The 1st International Symposium on Aquatic Product Processing 2013

\title{
PHYSIC AND CHEMICAL CHARACTERISTICS OF NATA DE SEAWEED FROM Eucheuma cottonii and Gracilaria sp.
}

\author{
Max R. Wenno 1)* Martha L. Wattimena1) Zulfikar A. Rumakey1) \\ Johanna L. Thenu'2) \\ 1)Departement of Aquatic Product Technology, Faculty of Fishery and Marine Science, \\ Pattimura University, Ambon. \\ 2)Fishery Education and Trainning Center, Ambon
}

\begin{abstract}
Seaweed (algae) is one of the potential export commodity to be developed. Kinds of seaweed that has a high economic value include: Rhodophyceae (red algae) as a produce of agar and carrageenan, Phaeophyceae (brown algae) as a produce of alginates. Seaweed potential of 1.2 million hectares, the potential production of dried seaweed on average 16 tons every year, however, seaweed explored just about two percent. This fact indicated that seaweed is one commodity that have the opportunity to developed, both in terms of aquaculture, biotechnology and processing. The aimed of this study was to determine the kinds of seaweed and the best ratio of filtrate and water, based on a physical test and determine the chemical composition of nata de seaweed.
\end{abstract}

Keywords: $\quad$ Eucheuma cottonii, Gracilaria sp., nata de seaweed, physic and chemical characteristics

\section{INTRODUCTION}

Commercial seaweed that have high economic value in Indonesia are grouped into five there are Eucheuma, Hypnea, Gracilaria, Gelidium, and Sargassum (Anggadiredja et al. 2010). The large quantities in Moluccas is Eucheuma, Gracilaria and Hypnea usually used by local people for consumption as food, besides used for export commodity (Sutomo 2006 in Siahaya $2011)$.

Low utilization of seaweed is one of the opportunities for the development of product diversification for example Nata de seaweed product. Nata de seaweed is inspired of nata de coco product that introduced in Indonesia since 1975. Products originating from the Philippines to take advantage of this coconut water, then lots of interest and developed using pollen from other kind of fruits. The abundance of seaweed result in Moluccas in particular, will be its own motivation to develop products based seaweed in this case is the nata de seaweed.

Until this day information about the utilization of seaweed in Moluccas still less, especially processing, kinds, row material and a ratio of materials in the processing. Therefore, the research in topic "physic and chemical characteristics of nata de seaweed from Eucheuma cottonii and Gracilaria sp" was studied. 


\section{MATERIALS AND METHODS}

\section{Materials}

This study used red seaweed (Rhodophyceae) from E.cottonii which originated from Wael coast, West Seram Distric and kind of Gracilaria sp. which originated from the Hutumuri coast, distilled water, acetic acid, sugar, amino dimethyl phosphate, starter bacteria Acetobacter xylinum and chemicals for analysis.

\section{Methods}

\subsection{Stages of research}

The research divided in two stages: firstly, making of nata de Seaweed with filtrate and water ratio according to treatment. The resulting of best quality Nata is determined by a physical and organoleptic test. Secondly, the best products in first stage was analyzed crude fiber, iodine, moisture, ash, protein, fat and carbohydrate content (by different).

\subsection{Treatments}

The treatment in this studied is kinds of seaweed $(A)$ with 2 levels $E$. cottonii $\left(A_{1}\right)$ and Gracilaria sp. $\left(A_{2}\right)$ and the ratio of filtrate and water $(B)$ with 2 levels 1: $19\left(B_{1}\right)$ and 2: $19\left(B_{2}\right)$.

\subsection{Data Analysis}

Data were analyzed descriptive and subjective parameters such as appearance, odor, flavor, texture, color and physical test such as thickness value and teeth cutting test using the Friedman test, followed by Multiple Comparison test (Wayne 1989).

\section{RESULTS AND DISCUSSION}

\section{Physical test}

1.1 Thickness values

E. cottonii with the filtrate and water ratio $1: 19$ showed the highest thickness value $(10.87 \mathrm{~mm}$ ) and the lowest showed by filtrate and water ratio $2: 19$ was $8.08 \mathrm{~mm}$ (Fig. 1).

Fig. 1 above shows that the thickness decreases with the addition of filtrate. The different kinds of seaweed will influence the content of the bacterial culture. Carrageenan produced by E. cottonii. Winarno (2008) maintained that carrageenan is a hydrocolloid compound consists of ester potassium, sodium, magnesium, and calcium sulfate, with galactose and 3.6 anhidrogalakto copolymers. The content of carrageenan and other minerals can also affect the fermentation medium that supports the activity of bacterial. Budiyanto (2004) reported that nata created by the bacterial A. xylinum on the surface of the medium, which contained sugar. In optimum conditions these bacteria has the ability to produce nata and if the optimum bacterial growth nata thickness will also be better. 


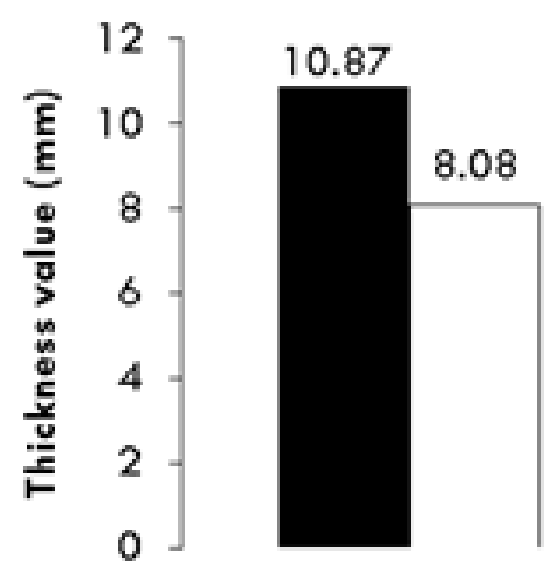

E. cottonii

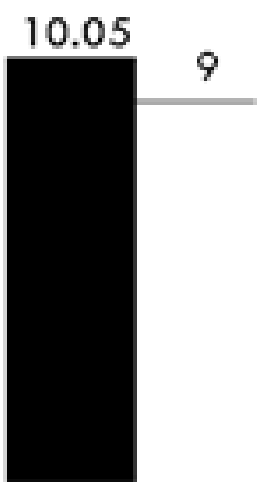

Gracilaria sp.

Figure. 1. Nata de seaweed thickness value.

: filtrate and water ratio (1:9) and $\square$ : filtrate and water ratio $(2: 9)$

1.2 Teeth cutting test

E. cottonii with the filtrate and water ratio $1: 19$ indicated the highest teeth cutting test value (7.41) and the lowest showed by Gracilaria sp. with the filtrate and water ratio $2: 19$ was 5.51 (Fig. 2).

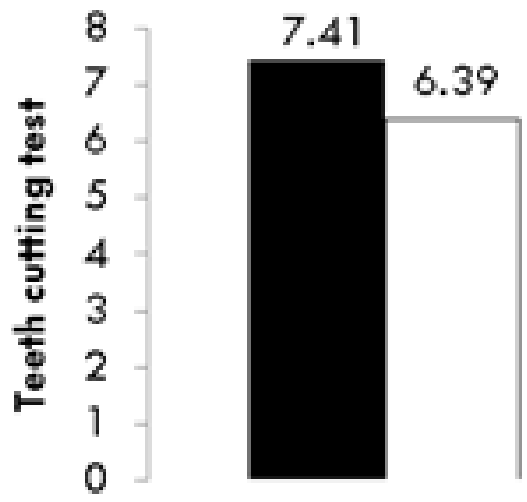

E. cottonii

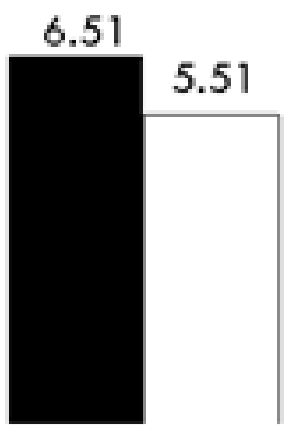

Gracilaria sp.

Figure. 2. Nata de seaweed teeth cutting test value. (1:9) and $\square$ : filtrate and water (2:9)

Fig. 2 above shows that the teeth cutting test value decline with the addition of filtrate and kind of seaweed. E. cottonii have a higher value than Gracilaria sp. Nata elasticity caused by fiber components contained in nata. Mineral contained in the medium contribute to determine the level of elasticity. Another factor that influence of nata elasticity is a long of fermentation and nitrogen sources used. Nata elasticity will also increase after boiled in sugar water. Nata is boiled in sugar water decreased elasticity and break more easily if bitten (Arsatmodio, 1996). 


\section{Organoleptic test}

The data reported that organoleptic value of nata de seaweed based treatments tested. E. cottonii with the filtrate and water ratio 1:19 showed the highest appearance value (7.08) and the lowest showed by Gracilaria sp. with the filtrate and water ratio 2:19 was 6.15. The appearance is one of the factors that contribute consumer level acceptance of a product. Good appearance such as shape and color, can increase product appeal (Rumakey 2011).

Table 1. Organoleptic value of nata de seaweed

\begin{tabular}{|c|c|c|c|c|c|c|}
\hline \multirow{2}{*}{$\begin{array}{c}N \\
0\end{array}$} & \multirow{2}{*}{ Treatment } & \multicolumn{5}{|c|}{ Organoleptic value } \\
\hline & & Appearance & Odor & Taste & Texture & Color \\
\hline 1. & $\mathrm{~A} 1 \mathrm{~B} 1$ & $7.08 \pm 0.20^{a}$ & $5.71 \pm 0.27^{a}$ & $6.90 \pm 0.47^{a}$ & $6.86 \pm 0.4^{a}$ & $6.95 \pm 0.55^{a}$ \\
\hline 2. & $\mathrm{~A} 1 \mathrm{~B} 2$ & $6.46 \pm 0.20^{\mathrm{ab}}$ & $5.26 \pm 0.20^{a b}$ & $6.23 \pm 0.5^{\mathrm{ab}}$ & $5.86 \pm 0.23^{a b}$ & $6.24 \pm 0.23^{a b}$ \\
\hline 3. & $\mathrm{~A} 2 \mathrm{~B} 1$ & $6.51 \pm 0.15^{\mathrm{ab}}$ & $5.26 \pm 0.26 \mathrm{ab}$ & $6.26 \pm 0.29 a$ & $5.95 \pm 0.45^{\mathrm{ab}}$ & $6.45 \pm 0.15^{\mathrm{ab}}$ \\
\hline 4. & $\mathrm{~A} 2 \mathrm{~B} 2$ & $6.15 \pm 0.75^{b}$ & $4.90 \pm 0.80^{b}$ & $5.7 \pm 0.23^{b}$ & $5.17 \pm 0.33^{b}$ & $6.68 \pm 0.80^{b}$ \\
\hline
\end{tabular}

Note : The numbers on the same row followed by different superscrips letter $(a, a b, b)$ indicate significantly different $(p<0.05)$.

E. cottonii with the filtrate and water ratio $1: 19$ showed the highest odor value (5.71) and the lowest showed by Gracilaria sp. with the filtrate and water ratio $2: 19$ was 4.90 . Soaking and cooking during process can reduce the acid smell of Nata products after fermentation. This process can eliminate the effect of acetic acid were added to the fermentation medium that does not affect the flavor. Anastasia and Eddy (2008) maintained that good nata quality had not flavorful cause it is composed of fiber and water.

Effendi (2009) reported that the most fiber content will be good for taste and flavor of nata. The highest and lowest taste indicated by treatment $E$. cottonii with the filtrate and water ratio $1: 19$ and Gracilaria sp. with the filtrate and water ratio $2: 19$ with values of 6.90 and 5.7 , respectively.

Nata de seaweed has a elasticity texture and a soft surface it caused by fiber content in nata. If fiber content higher the elasticity would be better. During of maturation, storage, or processing, cellulose and hemicellulose components be changes likewise the texture (Winarno 2008). The highest and lowest textures indicated by treatment $E$. cottonii with the filtrate and water ratio $1: 19$ and Gracilaria sp. with the filtrate and water ratio $2: 19$ with values of 6.86 and 5.17 , respectively.

Overall of color after fermentation is white and tanned white in surface. This indicated that color of media and will reduced by soaking and washing. Color of nata was influence by raw material (Nur 2009). This study showed that highest and lowest color resulting in treatment E. cottonii with the filtrate and water ratio $1: 19$ and E. cottonii with the filtrate and water ratio $2: 19$ with values of 6.95 and 6.24 , respectively.

\section{Chemical composition}

Proximate, crude fiber, and iodine Analysis of the best result on first stage (Table 2 ). The data showed that $97.96 \%$ is moisture content it is highest when compared with other chemical 
compositions. Moisture found on the product nata sources from the medium. moisture contained in the medium as a gel.

Another factor that influence the moisture content is the amount of sugar added. Protein and fat was found in the small part. Santoso (2004) maintained that average protein content of $E$. cottonii was $0.7 \%$. Seaweed fat content is very low, but the composition of fatty acids essential is important for human health. The proportion of Omega-3 and Omega-6 is high in seaweed. Winarno (1990) reported that these essential fatty acids for the body, especially the brain tissue membranes forming.

Table 2. Chemical composition value of nata de seaweed

\begin{tabular}{cccccccc}
\hline \multicolumn{5}{c}{ Proximate value } & \multicolumn{2}{c}{$\begin{array}{c}\text { Crude } \\
\text { fiber }\end{array}$} & \multirow{2}{*}{ lodine } \\
\hline Moisture & Ash & Protein & Fat & Carbohydrate & \\
\hline $97.96 \%$ & $0.06 \%$ & $0.66 \%$ & $0.54 \%$ & $0.78 \%$ & $0.27 \%$ & $19.56 \mathrm{ppm}$ \\
\hline
\end{tabular}

\section{CONCLUSION}

The best treatment in this research is $E$. cottonii with filtrate and water ratio 1:19 with a physical test; thickness value $10.87 \mathrm{~mm}$, teeth cutting test 7.41, appearance 7.08, odor 5.71, taste 6.90 , texture 6.86 , color 6.95 and chemical composition; moisture $97.96 \%$, ash $0.06 \%$, protein $0.66 \%$, fat $0.54 \%$, carbohydrate $0.78 \%$, crude fiber $0.27 \%$, and iodine content 19.56 ppm.

\section{REFERENCES}

Agustriningsih S. 2007. Physic and Chemical Characteristics Nata de Whey Which Combined With Symbiotic Whey Syrup During Storage.Thesis. Faculty of Animal Science. Bogor Agricultural University. Bogor .

Anggadiredja T.J, Zatnika A, Purwoto H, Istini S. 2010. Seaweed, Aquaculture, Processing and Marketing of Potential Fishery Commodities. Penebar Swadaya. Jakarta.

Apituley DAN. 2008. Food Chemistry Textbook. Department of Fisheries Processing Technology. Faculty of Fisheries and Marine Sciences. Pattimura University. Ambon Apridar. 2010. Marine Economy. Graha Ilmu. Yogyakarta.

Arsatmojo E. 1996. Formulation of nata de pina. Thesis. Faculty of Agriculture Engineering and Technology. Bogor Agricultural University. Bogor.

Budiyanto KA. 2004. Microbiology Application. First edition. Third Impression. UMM press. Malang.

Effendi NH. 2009. Effect of Mass Addition Starch (Starch Soluble) on Making Nata de Coco In Fermentation Medium Bacteria Acetobacter xylinum. Thesis. Faculty of Mathematics and Natural Sciences. University of North Sumatera. Medan.

Isti. 2005. Development of Value-Added Production of Milkfish Bond Less and Nata Agar. Fishery Infection Agency. Ministry of Marine Affairs and Fishery Republic of Indonesia. Jakarta.

Nur A. 2009. Nata de Cottonii Characteristics With The Addition of Amino Dimethyl Phosphate (DAP) and Glacial Acetic Acid. Thesis. Faculty of Fisheries and Marine Sciences. Bogor Agricultural University. Bogor .

Rumakey ZA. 2011. Effect of Seaweed Type to Organoleptic Quality and Viscosity of Seaweed Jam. Paper Report. Faculty of Fisheries and Marine Sciences. Pattimura University. Ambon.

Santoso A,Yumiko Y, Takeshi S. 2004. Minerals, Fatty Acids and Dietary Fiber Compositions in Several Indonesia Seaweeds. Indonesia Marine Science and Fishery Journal. 1 1:45-51.

Siahaya R. 2011 . Making Jam from Several Red Seaweed (Rhodophyceae). Thesis. Faculty of Fisheries and Marine Sciences. Pattimura University. Ambon. 
Wayne DA. 1989. Nonparametric Statistics. Interpreter by Kunjtoro W. PT. Gramedia. Jakarta.

Winarno FG. 1990. Seaweed Processing Technology. Gramedia Jakarta.

Winarno FG. 2008. Chemistry of Food and Nutrition. Mbrio press. Bogor . 